\title{
フランス首都圈の民間共同住宅におけるガルディアンに対する居住者の評価 THE RESIDENTS' OPINION TOWARD GARDIEN(NE)S OF PRIVATE APARTMENT HOUSES IN THE FRENCH METROPOLITAN AREA
}

\author{
関川＼cjkstart華*, 高田光雄** \\ Hana SEKIKAWA and Mitsuo TAKADA
}

\begin{abstract}
This research elucidates the residents' opinions regarding the caretakers called Gardien(ne)s of private apartment houses in the French Metropolitan Area. The number of Gardien(ne)s is in a decline after the war. This decline is attributed to privacy issues, that is, it will be easy to obtain information on residents' private lives, and to labour cost. However, the Gardien(ne)s often provide domestic services that supported the residents' lifestyle. Furthermore, as someone who are living in the vicinity, they also give the sense of security and presence. From these characteristics, the Gardien(ne)s are being upheld by the city dwellers. Moreover, compared to other management types, the cost is not particularly high. The decline of Gardien(ne)s is not due to the actualization of full-time caretakers demerits, such as live-in issues or labour cost, instead, it is natural to think that it is due to the diversification of management types.
\end{abstract}

Keywords : Gardien(ne), Residents' Opinion, Management, Apartment houses, French Metropolitan Area ガルディアン，居住者評価，住宅管理，民間共同住宅，フランス首都圏

\section{I .はじめに}

\section{1-1 研究の背景と目的}

日本の都心部の民間共同住宅の管理体制は、近年の社会的な構造 の変化によって、改めて検討される段階に来ている。

日本の共同住宅の管理の根本的な思想は 19 世紀のオクタヴィア. ヒルをルーツとしたイギリスの公共住宅の住居管理であり ${ }^{1)}$ 、これ は日本の初期の公的住宅の管理体制の確立と共に、後の民間共同住 宅の管理体制にも影響を与えている。1960 年代には、公共住宅の 管理戸数が急増し、さらに民間共同住宅の供給が拡大した。そのた め日本では効率的管理体制の構築が性急に求められ、根本的な管理 思想の議論が深められる機会がなかった。以後、社会背景の変化 から管理問題が発生したが、その度に実務課題解決型の研究がなさ れてきている。それらの研究結果の蓄積によって、日本独自の管理 体制が補強されてきた。しかし、民間共同住宅管理の思想の深化が なされないままでは、社会背景が移りゆくたびに表出する新たな管 理問題に直面しなければならない。そのため、社会背景の変化から 表出する管理問題に対して実務課題解決型の研究を行うだけではな く、管理論そのものの深化が必要である。

日本よりも民間共同住宅の管理の歴史の蓄積がある（イギリスに
対する）欧州諸国（以下、大陸）で現在も存続する伝統的管理体制 には、歴史に伴って発展してきた管理論の存在が期待できる。大陸 の管理論を把握するためには、まず、伝統的管理体制が現在も存続 している理由を明らかにすることが不可欠である。

大陸の中でもフランス首都圈注1) の民間共同住宅の管理としては、 19 世紀から存在する伝統的な住宅管理人、Gardien(ne) d'Immeuble (以 下、ガルディアン) をおく方式（以下、ガルディアン方式）がある主2)。 本研究では欧州大陸のフランス首都圈のガルディアン方式に着目す る。フランス国立統計経済研究所 (Institut National de La Statistique et des Etudes Economiques、以下、INSEE）の 1999 年の国勢調查 ${ }^{2)}$ によ ると、ガルディアンを置くパリ市の民間共同住宅注3) の住棟は約 6 割弱に及ぶ注4)

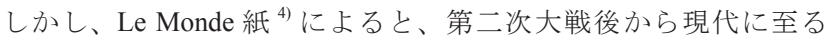
までの間にガルディアンの絶対数は減っており注5)、その理由とし て、居住者の私生活と距離が近いため居住者の情報を得やすいとい う住み込みの問題点や、人件費が高くつくことを挙げている注6)

現在この管理方式が都心居住者に肯定的に受け入れられているの か、或いは否定的に捉えられ排除されているのかは、実際に(1)フラ ンス首都圈の都心居住者がガルディアンに期待する業務内容、(2)管

\footnotetext{
* 京都大学大学院工学研究科 
表 1 ガルディアンに関する主な既往研究

\begin{tabular}{|c|c|c|c|c|}
\hline 発表年 & 著者 & 題目 & 分野 & 内 容 \\
\hline 1923 & René Mouquot & $\begin{array}{l}\text { De La Propagation d'Incendie, Source de Responsabilité, } \\
\text { Pour Le Gardien d'Un Immeuble }\end{array}$ & 法学 & $\begin{array}{l}\text { Mouquotは1896年の火災延焼責任がガルディアンにあるという判決について、疑問を持ち、判決の基 } \\
\text { 準になった条項Article1384を判例を通して分析した。延焼責任は出火原因を引引き起こした直接的関係者 } \\
\text { または所有者の責任であり、短絡的にガルディアンに責任を転嫁することは不適切であると示した。 }\end{array}$ \\
\hline 1943 & Jean Mégret & $\begin{array}{l}\text { Le Contrat de Gardiennage d'Immeuble de Rapport } \\
\text { Droits et Obligations du Concierge, Sa Responsabilité, } \\
\text { Responsabilité du Propriétaire de Son Fait }\end{array}$ & 法学 & 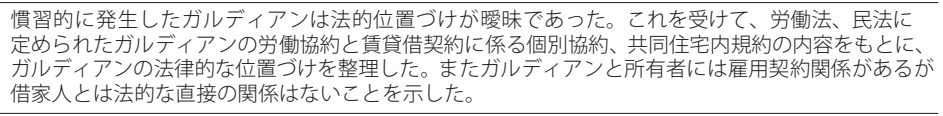 \\
\hline 1966 & $\begin{array}{l}\text { Ferdinand-Pierre } \\
\text { Reynes }\end{array}$ & La Situation du Gardien d'Immeubles & 法学 & 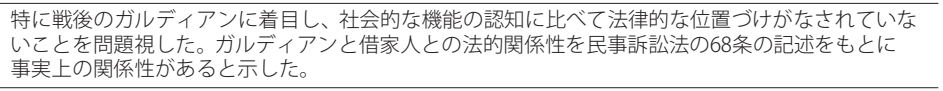 \\
\hline 1992 & $\begin{array}{l}\text { Jean-Louis } \\
\text { Deaucourt }\end{array}$ & Premières Loges, Paris et Ses Concierges au XIX Siècle & 歴史学 & $\begin{array}{l}\text { ガルディアンが一般化した19世紀を取り上げ、当時の裁判記録や新聞、風刺画、ボードヴィルの脚本 } \\
\text { をもとに、ガルディア社会的地位や居住者との関係などをとめている。 } \\
\end{array}$ \\
\hline 2004 & Hervé Marchal & $\begin{array}{l}\text { La Construction de L'Identité Sociale et Professionnelle } \\
\text { des Gardiens-concierges du Secteur HLM }\end{array}$ & 社会学 & 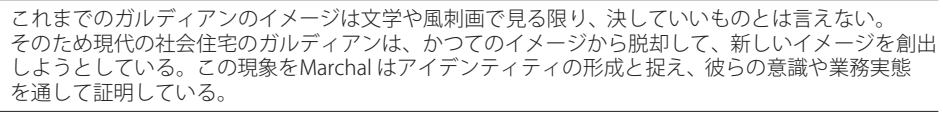 \\
\hline 2005 & Jean-Marc Stébé & La Médiation Dans Les Banlieus Sensibles & 社会学 & $\begin{array}{l}\text { 文献をもとに、フランスの社会住宅のガルディアンの設置に、イギリスのオクタヴィア・ヒルを } \\
\text { ルーツとした居住管理が影響を与えたとを確かめている。 }\end{array}$ \\
\hline
\end{tabular}

理費である Charge（シャルジュ、以下、負担金）の費用、(3)住み 込みの問題点として、人が常駐するということに対する居住者の認 識、を解明寸ることなしに判断できない。本研究では上記の (1)、(2)、 (3)から、都心居住者のガルディアンに対する評価を分析することに よって、フランス首都圈で伝統的管理体制の流れを汲むガルディア ンが存続し続けている理由を考察する。

\section{1-2 既往研究からみた本研究の位置づけ 1）共同住宅の管理の議論}

管理概念の構成をシステムとしてとらえて検討したものとして は、梶浦 ${ }^{7)}$ や延藤 ${ }^{8)}$ によるものがあげられる。まず、梶浦は管理 の概念を、運営管理、維持管理、生活管理に分けて、どの部分に所 有者や居住者が参与して管理主体となり得るのかを検討した。さら にそれを支える専門的知識を持った第三者の養成についても指摘し ている。また、延藤は、管理を統制的管理と愛着的管理が相互規定 関係で成立するとした。それを支えるコミュニティの形成や醸成に は拘束的共同性と自由的共同性が相互規定関係にあるとし、統制的 管理、愛着的管理の成立には「住み手の自在な発想と協力・行動」 が必要であると述べた。

さらに、近年の民間共同住宅の急増や、人口構成やライフスタイ ルの変化により現代に適した管理体制の再考が求められている。社 会背景の変化と従来の管理体制との称じれから、緊迫した管理問題 を実務的知見から解決しようとする研究が蓄積されている ${ }^{91}{ }^{10)}$ 。

本研究は民間共同住宅に合った管理思想を背景に持った管理体制 の検討を前提としており、この点で先行の実務的管理研究とは異な る。

共同住宅の管理を思想的側面から根本的に検討した研究として は、中島の研究があげられる。中島 ${ }^{1)}$ は公的共同住宅管理の水準の 向上のために、専門職の養成と居住者への管理教育の必要性が論じ られたイギリスのオクタヴィア・ヒルをルーツとした管理論に着目 した。本研究は、イギリスに対する欧州大陸の状況を対象に、この ような研究領域を補強するものであると位置づけられる。

\section{2）ガルディアン研究の流れ}

ガルディアンに関する研究は多くない。主な研究を表 1 に示した。 フランスにおけるガルディアン研究は、特に法学分野で、ガルディ アンの法律的位置づけを確かなものにしようとする流れで行われて いる。1923 年、Mouquot は 1896 年に起きた共同住宅における火災 延焼の責任の所在を分析することを通して、当時のガルディアンの
法的位置づけの曖昧さを指摘した ${ }^{11}$ 。ここれはガルディアンが慣習的 に生まれた職業であるためであるとして、1940 年代に入り Mégret はガルディアンの法的位置づけを、労働法や民法で定められた労働 協約や、賃貸借契約に係る私的な協約、共同住宅内の規約をもとに 整理した。さらにガルディアンと所有者には雇用契約関係があるが 借家人とは法的な直接の関係はないことを示した ${ }^{12}$ 。これれに対して Reynes は特に戦後のガルディアンに着目し、居住者に対して行わ れるガルディアンのサービス及びサポート等の社会的な機能の有用 性の割に、居住者との法的関係づけがなされていないことに疑問を 持った。Reynes は、借家人との直接的な明文化された法的関係性は 確かにないが民事訴訟法の 68 条の記述をもとに事実上の関係性が あることを示した ${ }^{13)}$

1992 年には Deaucourt は歴史学分野において、ガルディアンの存 在が一般化した 19 世紀の裁判記録や新聞、風刺画、ボードヴィル の脚本をもとに、ガルディアンの社会的地位や居住者との関係等 がまとめられている ${ }^{14)}$ 。Deaucourt の研究は、近代の民間ガルディ アンの歴史的資料の集積であり、現代におけるガルディアン研究に とって非常に意義深いものとなっている。社会住宅をフィールドに、 ガルディアンの現状を明らかにしたのは 2004 年の Marchal である。 Marchal らは所得による居住隔離が社会問題化しているフランス首 都圈の郊外地域において、社会住宅のガルディアンは業務上の役割 だけでなく社会的役割があることを示した ${ }^{15}$ 。また、同じ社会学分 野において、Stébé は、フランスにおける社会住宅のガルディアン の設置にイギリスのオクタヴィア・ヒルをルーツとした住居管理が 影響を与えたことを歴史的な文献をもとに確かめている ${ }^{16)}$ 。

このようにガルディアン研究は、慣習的に生まれたガルディアン という職業の現状に合った法的位置づけが戦前、戦後にかけて整理 され、近年になってその社会的役割の解明が進みつつある。民間共 同住宅のガルディアンを対象にフィールド調查を通してその現状を 明らかにした研究は、執筆者らによる先行研究が挙げられる。この 先行研究の中で、執筆者らは現代の民間共同住宅におけるガルディ アンの状況を把握するため、ガルディアンの歴史的経緯や業務内 容 $^{17)}$ 、フランスの管理体制におけるガルディアンの位置づけ ${ }^{3)}$ 、さ らに地域のガルディアンの人的つながりの実態 ${ }^{18)}$ を明らかにした。 それらの一連の研究で対象にしている民間共同住宅のガルディアン はこれまで特に調查困難とされてきたフィールドであり、その現 況をより具体的に分析するという点で先行研究との違いや学術的な 


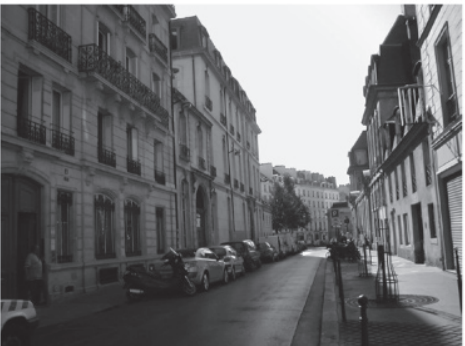

写真 1 調查対象地の様子 Béranger 通り ( 3 区)

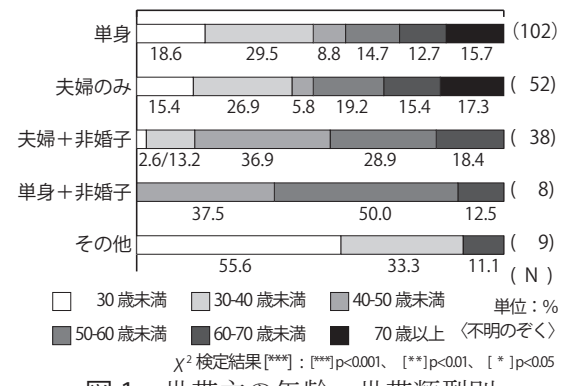

図 1 世帯主の年齢一世帯類型別一

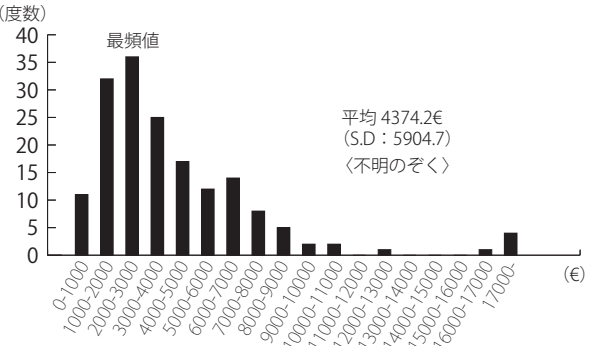

図 2 世帯の所得の度数分布
表 2 調査票の配布

\begin{tabular}{l}
\multicolumn{2}{c}{ ・回収状況 } \\
\hline 対象世帯数
\end{tabular}

表 3 回答者の基本属性

\begin{tabular}{|c|c|}
\hline 回答者の年齢 & 回答者の国籍 \\
\hline 30 歳未満 19.2 & フランス共和国 \\
\hline 30-40 歳未満 26.1 & 周辺ヨーロッハ諸国 \\
\hline 40-50 歳未満 13.1 & スイス・ドイツ・ベルギー・オランダ・ \\
\hline 50-60 歳未満 18.2 & ーイタリリア・ポルトガル \\
\hline 60-70 歳未満 11.7 & アフリカ諸国 (フランスからの独立年) 1.9 \\
\hline 70 歳以上 $\quad 11.7$ & 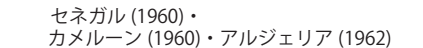 \\
\hline \multirow{4}{*}{$\frac{\text { 計 }(\mathrm{N}=211) 100.0}{\text { 単位 : \%〈不明のでく〉 }}$} & その他のヨーロッパ諸国 \\
\hline & ニギリシャ・ハンガリー・ルーマニア \\
\hline & 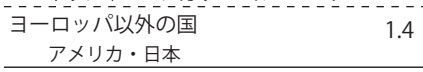 \\
\hline & 計 $(\mathrm{N}=214) \quad 100.0$ \\
\hline
\end{tabular}

表 4 世帯の基本属性

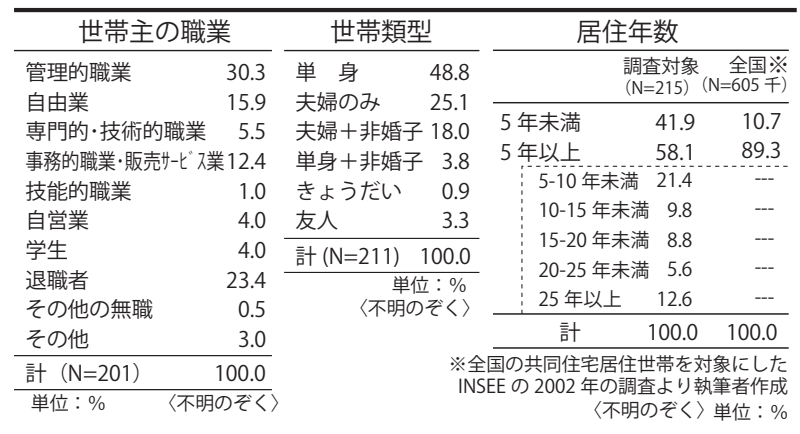

表 5 住宅の基本属性

\begin{tabular}{|c|c|c|c|}
\hline \multicolumn{2}{|c|}{ 居住階数 } & \multicolumn{2}{|c|}{ 住宅の所有関係 } \\
\hline R.C階 & 3.7 & 親:竌成の家に同 & 居 1.9 \\
\hline 第 1 階 & 13.1 & 持ち家 & 45.7 \\
\hline 第 2 階 & 18.2 & & 50.4 \\
\hline 第3 3 階管 & 17.3 & 社宅・寮なぞ & 1.0 \\
\hline $\begin{array}{l}\text { 第4 } 4 \text { 階 } 5 \text { 階 } \\
\end{array}$ & $\begin{array}{l}15.0 \\
17.3\end{array}$ & その他 & 1.0 \\
\hline 第 6 階以上 & 15.4 & 計 $(\mathrm{N}=210)$ & 100.0 \\
\hline 計 $(\mathrm{N}=214)$ & 100.0 & 単位：\%〈不明の & Dぞく〉 \\
\hline
\end{tabular}

表 6 住棟の基本属性

\begin{tabular}{|c|c|}
\hline 階数 & 商店や事務所の有無 \\
\hline ( 階建て) & 商店あり $\quad 21.9 \%$ \\
\hline-5 階建て) 36.9 & 1.2(S.D:1.2) \\
\hline 高層 (6 階以上) 62.1 & $75.3 \%$ \\
\hline 計 $(\mathrm{N}=198) \quad 100.0$ & $\begin{array}{l}\text { 平均事務所数 } 0.6(\mathrm{~S} . \mathrm{D}: 1.3) \\
\text { 平均住戸数 } 18.0(\mathrm{~S} \cdot 13 \cdot 0)\end{array}$ \\
\hline 単位：％〈不明 & 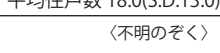 \\
\hline
\end{tabular}

価值がある。本研究では、ガルディアンのサービスの享受者である 居住者によるガルディアンに対する認識を明らかにしようとしてい る。これはガルディアンを置く管理方式の実態を生活者の視点から 把握するという意義がある。

\section{1-3 研究の方法}

都心居住者のガルディアンに対する評価を明らかにするために、 (1)フランス首都圈の居住者がガルディアンに期待する業務内容、(2) 負担金の費用、(3)人が常駐するということに対する居住者の認識を 把握する。海外をフィールドとするため言語的な障壁による調査困 難や誤解を避け、かつ、できるだけ多くの居住者のデータを集める ために質問紙調査法を選択した。調査項目は、回答者等の基本属性、 日常的な建物維持の業務執行主体、ガルディアンに期待する業務、 負担金の費用、ガルディアンの存在に対する認識等、である。調査 方法は次のとおりである。

フランス首都圈の中でも住戸単位で賃貸化した区分所有の民間共 同住宅が多く注7、さらにガルディアンがいる住棟の密度がもつと も高いパリ市を選定し 注8)、1〜20区の中で民間共同住宅が多い地 域を対象地とした ${ }^{\text {注9) }}$ (写真 1)。民間共同住宅の住棟をランダムサ ンプリングし、一住棟につき三世帯に調查票を配布した。調查票は 留置自記入後、フランス国内で郵送回収した。調查期間は 2006 年 $3 \sim 10$ 月である。調查票の配布、回収状況は、表 2 のとおりであ $る^{\left.3^{\text {ia }} 10\right)}$ 。得られた結果は統計的手法で分析し考察を加えた。

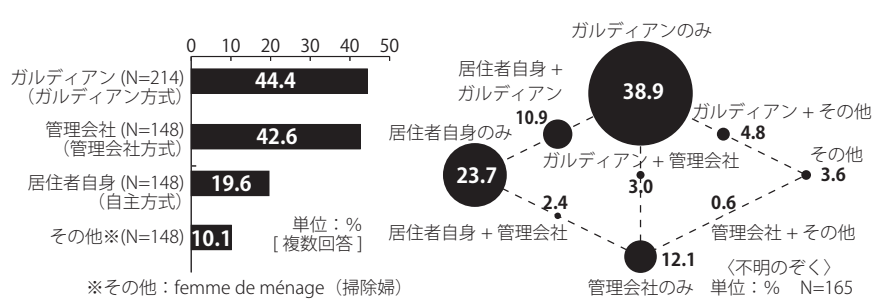

a. 主体の内訳（複数回答） b. 主体の内訳（単数回答）

図 3 日常的な管理の業務執行主体

\section{II. 調査対象の属性}

\section{2-1 回答者、世帯、住宅の基本属性}

回答者の年齢を 10 歳刻みにしたとき、30 歳代に最頻值があり、 平均年齢は 46.2 歳（標準偏差、以下 S.D:17.6）であった（表 3)。 65 歳以上は $17 \%$ を占める（2005 年次のフランス全体における 65 歳 以上人口比率は $16 \%$ である)。国籍はフランス人が 9 割以上を占め ていた。ガルディアンがいる生活をした経験がある回答者は 9 割弱 （87\%、N=215）であった。そのため、現在ガルディアンがいない場 合であっても、ガルディアンに対する認識等については、当時の経 験をもとに回答を依頼した。

世帯の基本属性について（表 4)、世帯主の平均年齢は 47.8 歳 (S.D: 17. 4) で、職業は管理的職業と退職者が合わせて半数以上を 占めていた。平均世帯人数は 1.8 人 (S.D: 1.0) と小規模であった。 世帯類型は寸べてが核家族で、単身世帯が半分を占めていた。世帯 類型別に世帯主年齢をみると（図 1)、単身及び夫婦のみ世帯に 70 歳代の世帯主の割合が他の世帯に比べて多くみられた。高齢の居住 者は、単身または夫婦のみで暮らしている。2002 年のINSEE によ るパリ市の共同住宅居住者の平均月収は 2905 ユーロ注11) (以下、 $€$ ) であり、それに対して調查対象世帯の月収を $1000 €$ 刻みでみてみる と、「2000〜3000€」と「6000〜 7000€」に山があり、平均月収は 4374.2€（SD : 5904.7）であった（図 2)。

居住年数は 5 年未満が 4 割強で、全国平均に比べて短期滞在の居 住者が多い状況にあった。調査対象の住宅の所有形態は、持ち家、 
表 7 住棟ごとの住宅数一管理の執行主体別一

\begin{tabular}{lccc}
\hline & $\begin{array}{c}\text { ガルディアン } \\
(\mathrm{N}=57)\end{array}$ & $\begin{array}{c}\text { 管理会社 } \\
(\mathrm{N}=19)\end{array}$ & $\begin{array}{c}\text { 自主管理 } \\
(\mathrm{N}=45)\end{array}$ \\
\hline 平均住宅数 (S.D) & $20.8(15.4)$ & $14.6(10.2)$ & $17.2(12.0)$ \\
最頻值 & 12 & 12 & 11 \\
最小一最大 & $4-80$ & $4-60$ & $5-47$ \\
\hline & t 検定結果: 有意差なし & 単位:戸
\end{tabular}

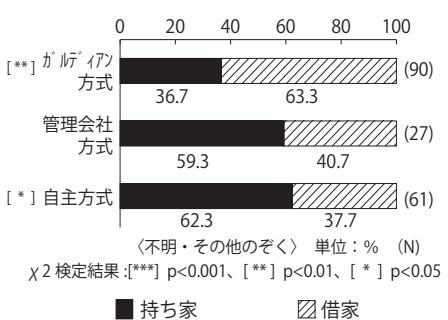

図 4 住宅の所有関係一管理方式別一

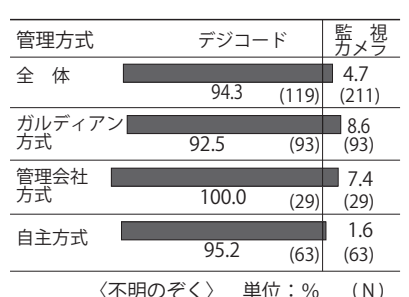

図 5 管理機器の導入
表 8 現行業務、期待業務の内容

\begin{tabular}{|c|c|c|c|c|c|c|}
\hline \multirow{2}{*}{\multicolumn{4}{|c|}{$\begin{array}{ll}\mathrm{a}: \text { 現在行われている業務 }(\mathrm{N}=90) & \\
\mathrm{b}: \text { : 期待する業務( }(\mathrm{N}=149) & \text { 単位:\%〈不明のぞく〉 }\end{array}$}} & \multirow{3}{*}{$\begin{array}{l}\text { 労働協 } \\
\text { 約上の } \\
\text { 業務 }\end{array}$} & \multicolumn{2}{|c|}{ 対象空間 } \\
\hline & & & & & 専有 & 共用 \\
\hline c:追加料金を払ってもしてもらいたい業務 $(\mathrm{N}=110)$ & $\mathrm{a}$ & $\mathrm{b}$ & $\mathrm{C}$ & & & |空間 \\
\hline 1.建物内のゴミ箱の処理 & 90.0 & 58.4 & 23.6 & $\bullet$ & & $\bullet$ \\
\hline 2.共用空間の掃除 & 84.4 & 57.0 & 30.0 & $\bullet$ & & $\bullet$ \\
\hline 3.建物内の見守り & 63.3 & 60.4 & 20.0 & $\bullet$ & & $\bullet$ \\
\hline 4.歩道·駐車場の掃除 & 45.6 & 43.0 & 16.4 & $\bullet$ & & $\bullet$ \\
\hline 5.緑地スペースの維持管理 & 37.8 & 32.2 & 15.5 & $\bullet$ & & $\bullet$ \\
\hline 6.高齢者の安否確認 & 30.0 & 70.5 & 24.5 & & $\bullet$ & \\
\hline 7.郵便物の配布 & 27.8 & 37.6 & 19.1 & $\bullet$ & & $\bullet$ \\
\hline 8.各専門業者との交渉 & 21.1 & 31.5 & 13.6 & $\bullet$ & & $\bullet$ \\
\hline 9.電気配線等の専門的技術を要する修理 & 17.8 & 40.3 & 26.4 & $\bullet$ & & $\bullet$ \\
\hline 10貸家の点検 & 13.3 & 24.2 & 21.8 & $\bullet$ & $\bullet$ & \\
\hline 11.家賃の徵収 & 10.0 & 12.8 & 5.5 & $\bullet$ & & $\bullet$ \\
\hline 12.負担金の徵収 & 6.7 & 11.4 & 4.5 & $\bullet$ & & $\bullet$ \\
\hline 13.居住者の私的な心配事の相談 & 6.6 & 15.4 & 9.1 & & $\bullet$ & \\
\hline 14.個人住宅のメッテテンスに関するアドバイス & 5.6 & 17.4 & 10.9 & & $\bullet$ & \\
\hline 15 病気の居住者の見舞い & 4.4 & 48.3 & 31.8 & & $\bullet$ & \\
\hline 16.居住者が重要な決定をする際の助言 & 4.4 & 19.5 & 10.0 & & $\bullet$ & \\
\hline 17.買い物代行 & 3.3 & 28.2 & 26.4 & & $\bullet$ & \\
\hline 18.居住者の話相手 & 3.3 & 17.4 & 15.5 & & $\bullet$ & \\
\hline 19.短時間の子どもの預かり & 2.2 & 41.6 & 41.8 & & $\bullet$ & \\
\hline 20.居住者と買い物 & 2.2 & 18.8 & 17.3 & & $\bullet$ & \\
\hline 21.居住者の家事手伝い & 1.1 & 28.9 & 33.6 & & $\bullet$ & \\
\hline 22.個人住宅のメンテナンスの手伝い & 0.0 & 25.5 & 28.2 & & $\bullet$ & \\
\hline
\end{tabular}

凡例

$60 \%$ 以上
借家がほぼ 5 割ずつであった。平均床面積は $62.4 \mathrm{~m}^{2}$ 、居住階数を みると地上階であるレッドショッセ（以下 R.C.）の居住者は極め て少なかった ${ }^{\text {注 }}{ }^{2}$ （前頁表 5)。住棟は 6 階以上の高さをもつものが 6 割以上あった（前頁表 6)。同じ住棟内に商店があると答えた世帯 は 2 割強で、事務所があると答えた世帯は 7.5 割であった。

一住棟あたりの平均的な住戸数は 18 戸であった（S.D:13.0、最 大 80 戸、最小 4 戸)。

\section{2-2 日常的な建物維持の業務執行主体}

前頁の図 3-a のように、日常的な建物維持の業務執行主体として 多くあげられたのはガルディアンと民間の管理会社であった。民間 の管理会社は掃除の専門業者や、総合的に管理業務を委託されてい る民間の会社である。次いで、居住者自身による自主方式が 2 割弱 あった。より詳しく見てみると（図 3-b)、ガルディアン方式のな かでもガルディアンのみが行う場合がもっとも多く、自主方式にガ ルディアンや管理会社を併用するところもみられた。

管理方式別に住宅規模の違いはなかった（表 7)。管理方式別に 住宅の所有関係をみるとガルディアン方式は借家世帯に、自主方式 は持ち家世帯にそれぞれ多い（ $\chi^{2}$ 検定の結果、有意差あり）（図 4$)$ 。 賃貸住宅がある住棟にガルディアンがいる傾向がある。

管理機器については、9 割以上の世帯の住棟がデジコード注 13 を 設置し、監視カメラはほとんど取り入れられていない（図 5)。

\section{2-3 小結}

1. 調查対象の中で 1 割弱が外国籍の居住者であった。世帯の規模は 単身世帯が半分近くを占めていた。65 歳以上の高齢者の割合は $17 \%$ であった。住棟は 20 戸程度の住戸数で構成され、所有形態 としては持ち家、借家が半分ずつであった。事務所や店舗が同じ 住棟内にあり、用途が混在している。調查対象者の所得はパリ市 の 2002 年の平均月収よりも約 $2000 €$ 高い。本研究の調查は民間 共同住宅で慣習的に発生したガルディアンに対する居住者の評価 を明らかにするために行った。そのため、対象は民間共同住宅の 居住者である。一般的に低所得層の居住者が多いとされる社会住 宅は対象外であるため、平均よりも所得が高い結果になっている と考えられる。

2. 日常的な建物の維持に伴う労務はガルディアンや管理会社が行っ ている。ガルディアンは住宅規模にかかわらず置かれており、特 に賃貸住宅がある住棟で雇われている傾向がみられた。

\section{III．ガルディアンに対する居住者の評価 \\ 3-1 業務に対する評価 \\ 1）現行業務の内容}

表 8 の a は、ガルディアンがいる住棟の世帯に対して、ガルディ アンの現行業務を質問した結果である。上から順に、回答が多かっ たものを羅列している。

ガルディアンの業務は、労働協約に記載された業務をベースにし て選択的に契約業務が決められるため、現行業務は、主に協約に記 載された業務である共用空間を対象にした管理業務を中心に挙げら れている。中でも、「建物内のゴミ箱の処理」や「共用空間の掃除」 については 8 割以上が行われていると回答している。次いで「建物 内の見守り」が 6 割強みられた。また、「高齢者の安否確認」につ いては協約上には記載されていないにもかかわらず、3 割の世帯が 


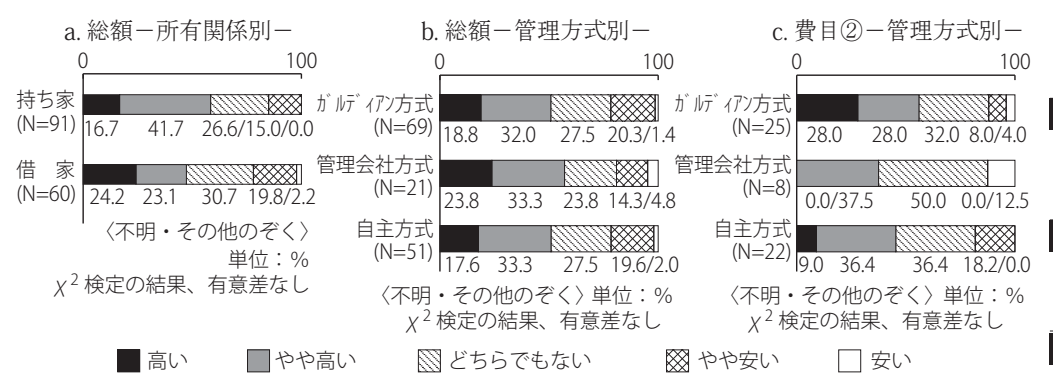

図 6 負担金価格に対寸る評価

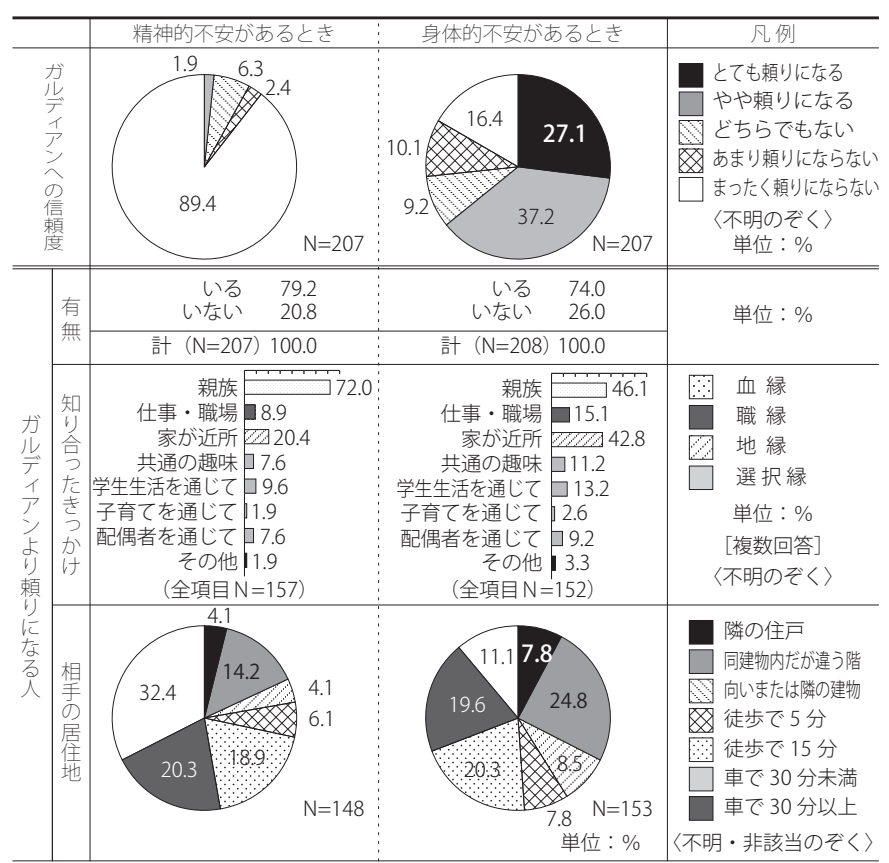

図 8 緊急時の拠り所

現在行われていると回答している。

\section{2）期待する業務内容}

表 8 の b は、ガルディアンに期待する業務について質問した結果 である。さらに、追加料金を払ってもしてほしい業務について聞い た結果が表 8 の c゙ある。これらについては、ガルディアンの有無 にかかわらず、調查対象全世帯に回答を依頼した。

労働協約上に記載されたいわゆるガルディアンの業務に加えて、 「高齢者の安否確認」や「病気の居住者の見舞い」、「短期間の子ど もの預かり」、「居住者の家事手伝い」、「買い物代行」、に対して期 待を持っている。以上の業務は専有空間にまで踏み込んだサービス であり、本来の共用空間の防犯や共有空間の日常的な建物維持に加 えて、緊急時、及び日常の家事サービスが期待されている。特に他 の業務内容に比べて「短期間の子どもの預かり」に関しては追加料 金を払ってでもしてもらいたいと考える居住者が多くみられた。

\section{3-2 負担金の費用}

フランスの共同住宅では、共用空間の管理のために負担金が、住 棟の居住者全員から徵収される。その費目は、(1)電力や水等のメー ター、エレベーター・共用の暖房等、設備機器の利用料等の建物利 用費、(2)共用空間の小規模修繥及び管理費、(3)ゴミの回収や消毒の ような公的サービスにかかる税金、となっている ${ }^{22}$ 。ガルディアン の給与は(2)に含まれる。

前頁の表 9 に示したように、調查対象の負担金の総額は平均

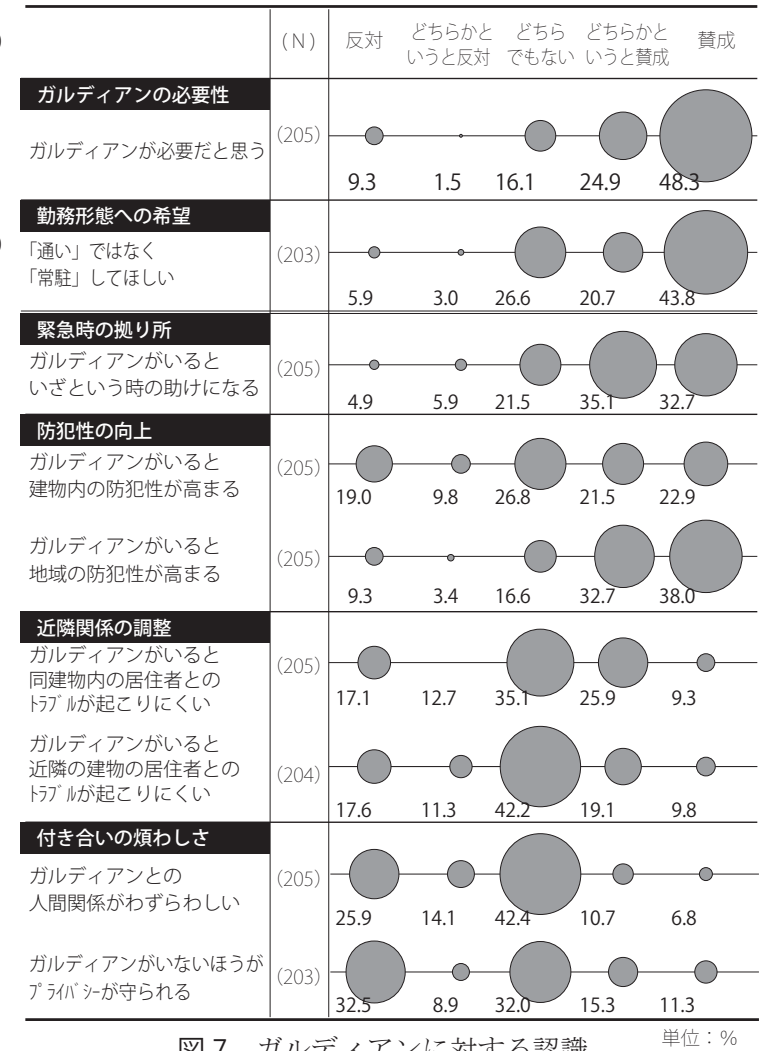

図 7 ガルディアンに対する認識

177. $4 € /$ 月で、 $0 € /$ 月から最大 $2433 € /$ 月まで大きな幅がある。所有 関係からみると（表 9)、持ち家世帯の負担金の総額は借家世帯よ りも約 $100 €$ 高く（ $\mathrm{t}$ 検定の結果、有意差あり）、これに対して、持 ち家世帯は「高い」「やや高い」と感じる割合が借家世帯よりも高 い傾向がみられた（ $\chi^{2}$ 検定結果、有意差なし）(図 6-a)。

管理主体ごとにみると（表 9)、有意差はないものの、ガルディ アンがいる住棟の世帯は、管理会社を導入する住棟の世帯や自主管 理をしている住棟の世帯よりも、負担金の総額が $20 €$ 強安かった。 ガルディアンの給与が含まれる費目である(2)共用空間の小規模修繕 及び管理費についても、ガルディアンがいる住棟に住む世帯は、管 理会社を導入している住棟に住む世帯や自主方式で管理を行う世帯 よりも、安い傾向がみられた（ $\mathrm{t}$ 検定の結果、有意差なし）。一方、 負担金に対する評価をみると、管理方式によって総額に対する評価 に大きな違いはなかったが (図 6-b)、ガルディアンの給与を含む 費目(2)に対しては、ガルディアン方式で管理を行う世帯の評価は「高 い」「やや高い」と感じる割合が、その他の管理方式の世帯に比べ てやや高い傾向がみられた（有意差なし）。

\section{3-3 人が常駐するということに対する居住者の認識}

図 7 は、居住者のガルディアンに対する認識を示したものである。 ガルディアンの必要性についてみると、7 割強の世帯が認めている。 また、勤務形態への要望としては、「通い」を望む世帯は 1 割にも 満たず、6 割強が「常駐」勤務を望んでいる。ガルディアンは住み 込みで勤務する場合が多いことがこれまでの研究の中で確かめられ ており、居住者もその状況を望んでいると言える。ここではガルディ アンが常駐することに対して、居住者がどのように評価をしている のかを「緊急時の拠り所」、「犯罪、近隣トラブルの回避」、「付き合 いの煩わしさ」という側面から明らかにする。 
表 10 自由記述の内容

\begin{tabular}{|c|c|c|c|c|}
\hline & & 記述内容 & の分類項目 & 自由記述欄記入者 122 人 $/ 263$ 件 \\
\hline \multirow{16}{*}{$\begin{array}{l}\text { 肯定的意見 } \\
\text { (225) }\end{array}$} & \multirow{6}{*}{\multicolumn{2}{|c|}{$\begin{array}{c}\text { 全居住者の生活に関して } \\
(114)\end{array}$}} & 共用空間の維持 / 常時 (38) & 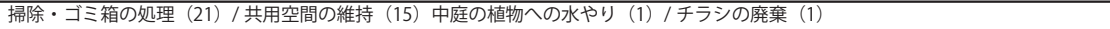 \\
\hline & & & 共用空間の維持 / 非常時 (21) & 配管・エレベーターなど機器の故障時、修理工を呼ぶ（15）/電球の交換（5）/不在所有者への連絡（1） \\
\hline & & & 建物内の見守り（24） & 来訪者の検閲・指導（9）/安全性の確保（8）/建物内の見守り（2）/住楝内の秩序を守る（2）/犯罪・押売りの予防（2）/建物内の事故対応（1) \\
\hline & & & 常駐する存在（18） & 人の存在感 (6) / 連絡すればすぐに来てくれる (6) / 常駐してくれる (5) /安心感 $(1)$ \\
\hline & & & & 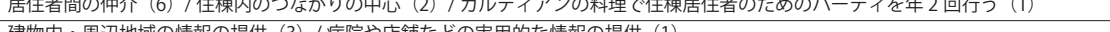 \\
\hline & & & & \\
\hline & \multirow{9}{*}{$\begin{array}{c}\text { 個別の居住者の } \\
\text { 生活に関して } \\
(108)\end{array}$} & \multirow{2}{*}{$\begin{array}{c}\text { 日常時 } \\
(16)\end{array}$} & 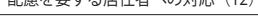 & 高齢者やハンデキャッブがある人の生活の助け（6）/居住者の話し相手・相談相手（3）/新規居住者への配慮（2）/子ども達の見守り（1） \\
\hline & & & 豕事の手伝い (4) & 掃除（2）/アイロンがけ（2） \\
\hline & & \multirow{3}{*}{$\begin{array}{l}\text { 非常時 } \\
\text { (29) }\end{array}$} & 家電機器の故障への対応 (13) & 修理工を呼ぶ（6）/ガルディアン自ら修理（6）/温水器の故障時、ガルディアン宅で入浴（1） \\
\hline & & & 体調不良時の対応（8） & 医者を呼ぶ（3）/体調不良時の対応（2）/買い物代行（2）/別居家族への連絡（1） \\
\hline & & & オートロックの事故の対応 $(8)$ & 閉じ込め・閉め出し事故時に預けていたスペアキーで対応（7）/消防を呼ぶ（1） \\
\hline & & \multirow{3}{*}{$\begin{array}{l}\text { 不在時 } \\
\text { (59) }\end{array}$} & 来訪者の対応 (44) & 別居家族の対応 (2) / ガス・電気等の公共サービスの職員や修理工の対応（13）/書留等、郵便物や宅配便の受取（29） \\
\hline & & & ペット・植物の世話（10） & 植物への水やり $(5) /$ /ペトの世世話（5） \\
\hline & & & 不測の事態への対応 (5) & 問題があればことづけてくれる（3）/鍵を忘れた息子を保護（1）/外で迷子になり自力で帰宅した娘を親の帰りまで保護（1） \\
\hline & & その他 & (4) & 引越しの手伝い (2) / 不測の取り立ての時の頼り先（1）/所有住戸を売却する時、買い手を見つけてくれた（1） \\
\hline & \multicolumn{3}{|l|}{ その他（3） } & 規約を変更してコストがかからないようにしたので、高くない（1）/80 歳以上なのによく働いてくれる (1) / 信頼できる人 (1) \\
\hline \multirow{6}{*}{ 否定的意見 } & \multirow{6}{*}{ (32) } & & 業務への消極性（9) & 何もしない (4) / 顔を合わせることがほどんどない (4) / 居住者との関係が希薄（1） \\
\hline & & & 評価できる業務がない (8) & 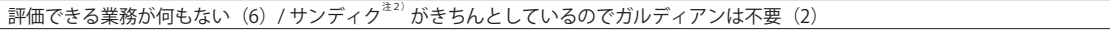 \\
\hline & & & 費用の高さ (6) & コストが高くガルディアンは廃止する・した（3）/ロジュを取り戻して売却・賃貸したい（2）/とてつもなく高くつく（1） \\
\hline & & & 業務の行き過ぎ（5） & 限度を超えた監視 (4) / パーティをすると警察を呼ぶ（1） \\
\hline & & & 情報の漏えい (2) & うわさ好き（1）/秘密が守れない（1） \\
\hline & & & その他（2） & 疎ましい存在（1）/ 時代遅れ（1） \\
\hline その他（6） & & & & ガルディアンがいない (3) /一般的にガルディアンの数は隇少している (3) \\
\hline
\end{tabular}

\section{1）緊急時の拠り所}

全体的に、いざという時の助けとしてガルディアンを頼りにして いる傾向がみられた（図７「緊急時の拠り所」）。またガルディアン の勤務形態について、「常駐」を希望する世帯には、いざという時 の拠り所と考える世帯が多い $\left(\chi^{2}\right.$ 検定の結果、 $0.1 \%$ 水準で有意差 あり)。表 10 はガルディアンに対する自由記述の内容を示したもの であるが、その中に「常駐する存在」に関する項目がみられる。具

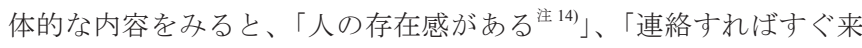

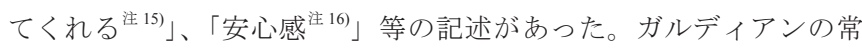
駐性がもしもの時の安心感につながり、評価されていることが分か る。

特に身体的な不安がある場合にガルディアンが「とても頼りに なる」、「頼りになる」と答えた世帯は 6 割強を占める（前頁図 8)。 具体的に、表 10 の「体調不良時の対応」という項目をみると、医 者や別居家族への連絡や、買い物の代行をしてくれたという記述が ある。

それに対して精神的な不安がある場合には「まったく頼りになら ない」と答えた世帯が 9 割を占めていた。ガルディアン以上に頼り になる相手が「いない」という世帯は、それぞれ 2 割強ずつある。 頼りになる相手と知り合ったきっかけをみると、身体的な不安を抱 える場合は「親族」、「家が近所」という回答がほぼ同じ程度の割合 でみられた。精神的な不安を抱える場合は、圧倒的に「親族」と答 える割合が多い。

頼りになる相手の居住地について、身体的な不安を抱える場合は、 7 割の回答者が徒歩 15 分圈内と答えている。一方の精神的な緊急 時の場合でも、 5 割弱が徒歩 15 分圏内にいると答えている。

\section{2）犯罪、近隣トラブルの回避}

図 7 の防犯性の向上をみると、「建物内の防犯性が高まる」とい う項目について、賛成と反対に意見は分かれている。表 10 には「建

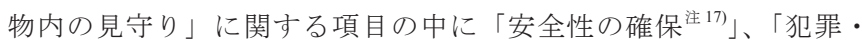

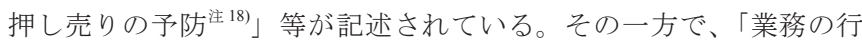
き過ぎ」に関する項目に「限度を超えた監視注 ${ }^{19} 」$ とあり、プライ バシー問題を訴える居住者の存在も、限定的ではあるが確認できた。 図 7 の「近隣関係の調整」の建物内や近隣の居住者とのトラブル
に関する認識をみると、「どちらでもない」と答える世帯が最も多 くを占め、さらに「反対」と答える世帯もあった。表 9 には「近隣 関係の調整」に関寸る項目がある。具体的な内容には「居住者間の 仲介注 201 、「住棟内のつながりの中心注 211 等という記述がある。こ れらはガルディアンを介して居住者同士が知り合いになるという近 隣関係の初期段階であり、トラブルの解決に関しては記述がない。

これに対し、地域の防犯性について図 7 の「地域の防犯性が高ま る」という項目をみると、「賛成」と答える世帯が 7 割強を占めて いた。ガルディアン一人一人に対しての防犯やトラブル回避の期待 はみられないが、ガルディアンが複数集まる地域では、その存在や 紐帯が防犯性に寄与寸ると居住者にみなされていると考えられる。

\section{3）付き合いの煩わしさ}

付き合いの煩わしさについて、図 7 の「ガルディアンとの人間関 係が煩わしい」という項目に対して「どちらでもない」と回答する 無関心な居住者層は 4 割強を占め、最も多い。次いで「反対」と回 答した世帯は 2 割強みられた。それらを合わせて 7 割弱の世帯は、 煩わしさを特には感じていないとみなすことができる（図 7)。

「ガルディアンがいないほうがプライバシーが守られる」という 項目については、「どちらでもない」と「反対」と答える世帯がそ れぞれ 3 割強ずつみられた。プライバシーの問題については無関心、 或いは気にしていない世帯が半数以上を占める（図 7)。

一方、表 9 の自由記述では、「業務の行き過ぎ」として「限度を

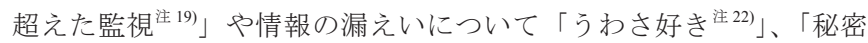

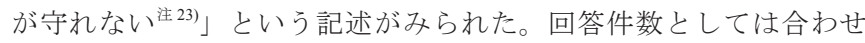
て 6 件と、少数意見ではあるが、プライバシーが侵されていると感 じる居住者の意見が明記されていた。

\section{3-4 小結}

1. ガルディアンは基本的に協約上に記載されている建物内の見守り や共用空間の日常的な維持管理業務を中心に行い、それに加え、 協約には記載がない高齢者の安否確認を特別に行っている。

2. ガルディアンに期待する業務としては、ガルディアンの本来の業 務である共用空間の防犯や日常的維持管理業務に加えて、専有空 間にまで踏み込んだ、緊急時及び日常の家事サービスが挙げられ た。ガルディアンは、家事面から日常生活を下支えする役割を期 
待されている。

3. 負担金は住棟によって様々で、最大額と最低額に大きな幅がみら

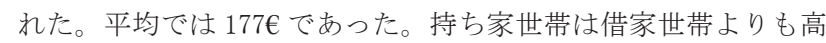
い負担金を支払っており、それに対して「高い」と感じている傾 向がみられた。管理主体ごとに、負担金の額に大きな違いはみら れなかったが、ガルディアンがいる住棟に住む世帯の負担金の評 価は他の世帯に比べて「高い」と感じており、ガルディアンに対 する居住者の金銭的評価は㛜しいという状況が明らかになった。

4. ガルディアンに常駐勤務を望む世帯は半数以上に及び、特に常駐 を望む世帯は、いざというときの拠り所としてガルディアンを頼 りにしている傾向がみられた。精神的な支えとしてではなく、身 体的不安がある場合に関係者との連絡や家事サービスを行う主体 として頼りにされている。その一方で、少なくとも約半数の世帯 が身体的不安と精神的不安に対して、ガルディアンより頼りにな る相手が徒歩 15 分圈内に住んでいると答えている。ガルディア ンは緊急時の人的セーフティネットとして捉えられている。

5. 一人のガルディアンの存在ではなく、地域にガルディアンが複数 で存在することが、犯罪を抑制する効果があると居住者は評価し ている。またガルディアン自身に近隣トラブルを回避、制御する 可能性があると考える居住者はほとんど存在しなかった。個々の ガルディアンの犯罪抑制効果やトラブル回避能力の有無ではなく、 ガルディアンが近隣のガルディアンと関係を有していることが居 住者評価の重要な根拠となっていると考えられる。

6. 機械管理等とは違い、ガルディアンは生身の人間が居住者の生活 圈に常駐して管理業務を執行する。そのため、付き合いの煩雑さ や、プライバシー問題が予測された。7割近くの世帯が、無関心 或いは問題はないとしている一方で、プライバシー問題を訴える 居住者の存在が、限定的ではあるが確かめられた。

\section{$\mathrm{IV}$ 結論}

本研究は、大陸の中のフランスにおける、管理論の把握を目指し、そ れが反映していると考えられる伝統的管理体制の現状を明らかにしようと している。本稿では、ガルディアンの業務、負担金の費用、住み込み の管理主体の存在という三点に対する居住者の評価を解明することで、 伝統的管理体制が現在も存続している理由について以下の通り考察を 行った。以下に結論を示す。

ガルディアンがいる住棟に住む世帯は半数以上見られ、一定の割合 で存続していることが明らかになった。

本研究の結果によれば、高齢者の安否確認をガルディアンが実際に 行っており、緊急時及び日常の家事サービスに関して居住者からの期 待が寄せられていることがわかった。それらの業務は、ガルディアンにとっ ては契約業務ではない居住者の個別的な専有空間で発生する福祉的 な社会ニーズに対するサービスやサポートである。つまり、本来は、日 常的な建物の維持管理を行う管理主体が、居住者の福祉的な社会ニー ズを補足しており、居住者からもそれが期待されている。ここから、物や財、 及び空間というハードと、それを利用して営まれる居住者の生活というy フトの両者を、管理の対象領域と寸る管理概念が、ガルディアン方式に は潜在していることがわかった。フランスの共同住宅の伝統的な住宅管 理人が、物や財及び空間の維持管理の担当者として機能しているだけ でなく、居住者の自立を補足的に支えるといら程度の地域福祉の担い手
として、一役を果たしていることが確認された。

その一方で、ガルディアンの絶対数は減少傾向にある。人権費が高く つくことや、常駐や住み込みによるプライバシー問題等の、人が常駐す る管理方式の短所が、減少理由として一般的に言われてきている。費 用面では、ガルディアンに対する居住者の金銭的な評価が厳しい、と いら現状が確かめられた。これは、区分所有者がガルディアンの必要性 を考えるとき、管理人室を併設する給与住宅の維持のための出費をする か、又はそれを賃貸や売却することで管理用経費を削減するかといら判 断に迫られるため、ガルディアンの存在に対する金銭的な評価が厳しく なっているものと考えられる。しかし実際のところは、人が常駐する管理 方式には、必然的に費用がかかると予測されるのにもかかわらず、今回 の調査では、ガルディアン方式と他の管理方式との間には費用の有意 差は見られなかった。高い人件費が実際に支払われていることが、ガル ディアンの減少傾向に影響しているとする Le Monde 紙の内容を必ずし も裏付ける結果ではなかった。今回の調查の結果はむしろ、当然支払 われているはずの費用が、払われていないという、違和感のある現状と してとらえることができる。人が常駐する管理方式に対して妥当な管理費 用が負担されるべきである。

また、プライバシー面については、今回の調査で、実際にプライバシー 問題を訴える居住者の存在が確認できた。プライバシー問題は、人に よる管理である限り、表出を免れない問題である。これについては、ガ ルディアンに対する守秘義務に関する教育プログラムの設置と積極的な 受講を促すシステムの構築が対応策として考えられる。

ガルディアンは、建物の日常的な維持管理業務だけでなく、居住者 の福祉的社会ニーズに対応する人的、対人サービス提供者である。ガ ルディアン方式は、建物の日常的な維持から、そのサービスの範囲を、 建物と居住者の生活の間に発生する地域福祉一と進展させている。この 点が居住者から評価されて、現在も存続している理由であると考察する。

\section{謝辞}

多忙な日常生活のなか、居住者の方々には我々の研究意図を汲み、 調查にご協力いただいた。またフランス、ストラスブール大学第 2 大学院社会学都市計画分野 Maurice Blanc 教授、及びナンシー第 2 大学社会学部 Jean-Marc Stébé 教授、Hervé Marchal 博士には、研究 に対して有意義なコメントをいただいた。記して感謝申し上げます。

\section{注}

注 1) 本研究における首都圈とはパリ市と周囲 7 県を含む地域、イルドフラン ス地方を指す。

注 2) ガルディアンは、フランス首都圈を中心に、建物内の警備や共用空間 の掃除やゴミ処理などの日常的な維持管理業務を行うために、19 世紀頃か ら庶民階層の民間共同住宅に置かれ始めた。現在、ガルディアンのほかに、 居住者自身が直接、日常的な建物の共用空間の維持を行う方式（以下、自 主方式）や、管理会社から派遣された職員が行う方式（以下、管理会社方 式）がある。自主方式、管理会社方式、ガルディアン方式のいずれにせよ、 フランスの民間共同住宅では 1965 年に定められた法律によって、区分所 有者組合である Syndicat（以下、サンディカ）という組織と、管理者であ る Syndic（以下、サンディク）の設置が義務づけられている。管理上の責 任はサンディクにある。

注 3) 本研究では、フランスの代表的住宅像として民間共同住宅に焦点を置い ている。フランスの都市部では、ハード面では中世都市らしさを残しつつ、 老朽化が問題視されている内部設備の改善をはかる一方で、ソフト面では 第一次世界大戦後の住宅危機の対策として大量供給された社会住宅政策を皮 
切りに、「石からヒトへ」の住宅政策が展開されている。ハードの供給だけ ではなく、生活困穿者への家賃補助なども住宅政策として行われてきている。 このような背景のもと、民間共同住宅では、家主と借家人だけでなく、そ こに伝統的に配置されているガルディアンが主体となって住生活を形成し てきている。国からの補助を受けている社会住宅または家賃補助を受けて いる階層とは違い、民間共同住宅の一般的な区分所有者は自らの経済状況 の範囲内で、共同的に住生活のサポート（維持管理業務など）を行うガル ディアンを雇用し、自律的に住生活の困難を解消しながら来ているという 状況が慣習的に存在している ${ }^{3)}$ 。

注 4)2009 年 12 月現在で、パリ市におけるガルディアンがいる住棟数のデー夕 は、1999 年国勢調査結果として、インターネットサイト上で公開されてい るものが最も新しい。

注 5) パリ市におけるガルディアンの数を示した資料は非常に少なく、詳細な 経年変化の把握は困難である。数少ない資料の中でも、文献 5)、6)による とガルディアンの数は、1864 年には約 46000 人、1874 年には 61794 人、 1939 年から 1945 年の間に約 85000 人にまで増加した。しかし、1965 年に は約 60000 人へと減少し、さらに文献 2) によると、1999 年のガルディア ンがいる住棟数は 51920 棟と記されており、ガルディアンの絶対数は確か に減少傾向にある。

注 6) 文献 4) の Peillon は、フランスを代表する写真家、Robert Doisneau の言 葉を引用して、「il y avait parfois dans ce métier "des bourriques autoritaires qui connaissaient tout de la vie privée des gens, ce qui représentait des abus possibles". この職業（ガルディアン）の中にはしばしば『人々の私生活の全てを知る、 横暴な警官』がいたものだった、『これ（ガルディアン）は可能な限りの 職権乱用を象徵していた。』(執筆者訳)」と記述し、住み込みという勤務 形態から、業務上、居住者の私生活の情報を知り得る立場にあることを示 している。それに加えてPeillon は、社会住宅を運営する公的セクターの 報告を引用しながら、「"Pour un immeuble de trente logements, l'entretien ménager et les sorties de poubelles coûtent 25000 francs par an, à comparer avec un coût minimal de 60000 francs pour le salaire du gardien auquel il faut ajouter 20000 francs de manque à gagner sur le logement de fonction."『60000 フランというガ ルディアンの最低給与に比べ、30 戸から成る住棟の、維持管理やゴミ箱 の処理にかかる費用は年間で 25000 フランである。（住み込み用の）給与 住宅の設置に、をと 20000 フランかかる。』(執筆者訳)」と記述し、ガルディ アンの人件費が高いことを示している。以上の結果として、ガルディアン を「Espèce en voie d'extinction 絶滅危惧種」と象徴的に表現し、「Résultat: "Il $\mathrm{y}$ aurait bien actuellement une diminution régulière du nombre de gardiens d'immeuble" selon le rapport du Conseil national de l'habitat, même si "aucune donnée chiffrée sérieuse n’a pu être recueilliée". 結果 : Conseil national de l'habitat（1983 年から 現在に至るまで、建設と居住を司る省の下に設置されている諮問機関。） の報告書によると、『これまで一つとして正当な数量データが集められ得 なかった』が、『目下、ガルディアンの数が規則的に減少している』(執筆 者訳)」と記述している。

注 7) 文献 19) をもとにフランス首都圈の状況をみた。区分所有住棟内に占め る借家の割合は $46 \%$ に及ぶ。文献 20) によると平成 5 年住宅統計調查を通 して算出した我が国の首都圈における「分譔マンションの賃貸化」、つま り区分所有住棟内における借家の割合を示寸「持家系住棟内賃貸率」は、 中層及び高層の区分所有共同住宅で、いずれも約 $21 \%$ であった。ゆえに日 本の首都圈における状況よりもフランスの首都圈における区分所有住宅の 貢貸化率はより高く、所有関倸が複雑化していると言える。

注 8) 文献2)をもとに執筆者が計算したところ、首都圈主要 7 都市における「ガ ルディアンがいる住棟密度」は平均 160 棟 $/ \mathrm{k} \mathrm{m}^{2}$ であった。これに対して パリ市の同值は 493 棟 $/ \mathrm{k} \mathrm{m} \mathrm{m}^{2}$ であった。

注 9) 以下、調查対象地別の対象数（有効回収率\%）である。1区: 29（27.6）、2 区: $34(29.4) 、 3 区: 30 （ 26.7) 、 4 区: 56(12.5) 、 5 区: 38 （ 29.7) 、 6 区: 22$ (40.9)、7区:83 (14.5)、8区:18 (11.1)、9区:27 (18.5)、10区: 20 (10.0)、11 区:37 (24.3)、12 区: $64(28.1) 、 13$ 区:26 (30.8)、14 区: $92(22.8) 、$ 15 区: $22(22.7) 、 16$ 区: $89(25.8) 、 17 区: 17 \quad(11.8) 、 18$ 区: $51 \quad(21.6)$, 19 区: $100(21.2) 、 20 区: 114(18.4)$ 。

注 10) 本調查のサンプル抽出率は母集団の $0.1 \%$ 、回収率 $22.2 \%$ である。本調 查は、プライバシー意識が非常に高いパリ市で、外国人である執筆者が、 同行者 0 ～ 2 名と共に行った。(1)調查員数の確保に限界があったこと、(2) プライバシーを守ろうと言う、対象地居住者の意識が高いこと、が本調査
の限界である。これに対し、執筆者は、限界1にについては、現地に 1 年半 滞在し調查を繰り返し行うことでサンプル数をできるだけ多く確保しよう と試みた。さらに限界(2については、現地の大学院の学籍を確保し、調査 員の身分及び調查概要を対象に伝えやすい状況を作ることを試みた。それ らの状況を踏まえると、本調查の対象は、調查の趣旨を理解し、調查協力 に積極的な居住者層であると言える。さらに、言語的な壁があること、プ ライバシーを守る意識が高い地域であること等の要因で、これまでフィー ルド調査が大変困難であった。ここで、約 87 万戸の民間共同住宅を対象に、 必要調查標本数を推計してみると、安全率を見込んだ場合、当調査のサンプ ル数は若干少なめであった ${ }^{211}$ 。

注 11) 換算レートは 2002 年は $1 €=118$ 円、2006 年は $1 €=147$ 円であった。 注 12) 多くの場合、R.C. にはガルディアンの居住空間が併設された管理人室、 $\operatorname{loge}($ ロジュ)や店舗等があり、居住者の空間は第 1 階（日本の 2 階にあたる） 以上にある。

注 13) デジコードとは数字を入力するタイプの電子錠のことである。Deaucourt によると、ガルディアンの前身となった職業は、中世に貴族の屋敷の門番 として雇われたスイスやポルチェと呼ばれた門番であるとされている ${ }^{14)}$ (敷地内に入るための) 門の開け閉めと人の出入りの監視が主要な業務で あった。19 世紀、コンシエルジュやガルディアンと呼ばれる住宅管理人と して庶民の共同住宅に配置されるようになってからもこの業務は、共同住 宅住棟の大門（建物内へ入るための門）の開閉と人の出入りの監視という 形で引き継がれた。当時の大門は、門限までは施錠されず、門限を過ぎる と施錠されるようになってるところが多かった。門限を越えて帰宅した居 住者は大門にある呼び鈴を鳴らし、深夜であってもガルディアンが大門を 解錠するための紐、cordon（コルドン）を引く仕組みになっている場合が 多かった。この業務は 20 世紀になってから人道的視点から改善され、機 械化されデジコードの導入が進められるようになった。

注 14)「La présence humaine irremplaçable, vis-à-vis des personnes seules ou isolées. 人の存在、一人暮らしや孤立した人々にとってかけがえのないもの。」 (No.76、60 歳、男性、フランス人、単身世帯) 、ほか 5 件。

注 15)「C'est très utile de savoir qu'il y a quelqu'un que l'on peut appeler. 呼べる人が いると分かっていることがいい。 (No.57、25 歳、女性、フランス人、きょ うだいと二人暮らし)、ほか 5 件。

注 16)「Sécurisation d'immeuble. 建物内における安心感。」(No.137、42 歳、男性、 フランス人、夫婦+非婚子)、ほかなし。

注 17)「Participation à la sécurité de l'immeuble. 住棟内の安全性に寄与する。」 (No.31、53 歳、女性、フランス人、夫婦＋非婚子世帯)、ほか 7 件。

注 18)「Cela évite les vol, le démarchage à domicile- Cela permet de circuler dans les différentes portes de l'immeuble sans problème. 難なく、建物内のドアからドア 一と渡り歩くような泥棒や訪問販売を遠ざけてくれる。」(No. 143、55 歳、 女性、フランス人、夫婦のみ世帯)、ほか 1 件。

注 19)「surveillance abusive. 限度を超えた監視。」（No. 25、47 歳、女性、フラ ンス人、単身世帯) 、ほか 3 件。

注 20)「Médiateur entre les différentes résidents. さまざまな居住者間の仲介者。」 (No.67、38 歳、女性、カメルーン人、単身世帯)、ほか 5 件。

注 21)「Les gardiens sont l'âme de la vie en société des immeubles parisiens. ガルディ アンはパリの住棟の社会生活の中心人物である。」(No.14、34 歳、男性、 フランス人、単身世帯)、ほか 1 件。

注 22)「Gardien vit avec ragots. ガルディアンは噂話と生きている。」(No. 25、 47 歳、女性、フランス人、単身世帯) 、ほかなし。

注 23)「Pas discret 秘密が守れない。」(No.171、35 歳、フランス人、単身世帯) 、 ほかなし。

\section{参考文献}

1) 中島明子: イギリスの地方自治体における住居管理, 京都大学, 工学博士 学位論文, 1992

2)INSEE : Recensement de la Population Mars 1999, Les Résultats, INSEE サイト, http://www.recensement-1999.insee.fr/RP99/rp99/page_accueil.paccueil，2009 年 12 月 1 日参照

3) 関川華, 高田光雄 : フランス首都圈の民間共同住宅におけるガルディアン が組み込まれた管理体制に関する研究, 日本建築学会計画系論文集,

No.647, pp.1 8, 2010.1

4)Peillon Antoine : De la < bignole > à la gardienne, Le Monde, 1989.5.25, p.12 
5)Marcheix Claude : Petite sociologie des concierges parisiens, TENDENCES, No.33, pp.97-120, 1965.2

6)Marchal Hervé : Le petit monde des concierges.Un métier au cour de la vie HLM, Editions de L'Aube, 2005

7) 梶浦恒男 : 新世紀のマンションー管理・震災・建て替え・更新を解く, 彰国社，pp. $151 \sim 178 ， 2001$

8) 延藤安弘：マンション管理とコミュニティ形成, 集合住宅管理の課題と展 望一都市研究報告第 8 号一, 神戸都市問題研究所編, 勁草書房, pp.106 118,1984

9) 平田陽子, 梶浦恒男, 斎藤広子 : 分譲共同住宅における管理参加困難層に 関する研究，日本建築学会計画系論文報告集， No.405, pp.129 140, 1989. 11

10) 斉藤広子，梶浦恒男，平田陽子：分譲共同住宅における賃貸化と管理に 関する研究，その 1 賃貸化の状態と管理に及ぼす影響, 日本建築学会計画 系論文報告集，No.422，pp. $97 \sim 106,1991.4$

11)René Mouquot : De La Propagation d'Incendie, Source de Responsabilité, Pour Le Gardien d'Un Immeuble，ポワティエ大学，法科学博士学位論文，1923

12)Jean Mégret : Le Contrat de Gardiennage d'Immeuble de Rapport, Droits et Obligations du Concierge, Sa Responsabilité, Responsabilité du Propriétaire de Son Fait，パリ大学，法学博士学位論文， 1943

13)Ferdinand-Pierre Reynes : La Situation du Gardien d'Immeubles，トゥールーズ
大学, 法学博士学位論文, 1966

14)Deaucourt Jean-Louis 著, 関川千尋, 関川華訳 : 初期の管理人小屋, 19 世 紀のパリとパリのコンシェルジュ, Premières Loges, Paris et Ses Concierges au XIX Siècle, Paris Aubier, 1992

15)Hervé Marchal : La Construction de L'Identité Sociale et Professionnelle des Gardiens-concierges du Secteur HLM，ナンシー第二大学，社会学博士学位論文，2004 16)Jean-Marc Stébé : La médiation dans les banlieus sensibles, PUF, Paris, 2005 17) 関川華, 高田光雄 : フランス首都圈における民間共同住宅の管理人の役 割に関する研究，日本建築学会計画系論文集，No.632，pp.2025～2032, 2008. 10

18）関川華，高田光雄 : フランス首都圈における民間共同住宅の管理人同士 及び管理人と居住者の相互関係，住宅系研究報告会論文集 3, pp.159～164, 2008. 12

19)INSEE : Les conditions de logement en Île-de-France en 2002，2004.10

20) 森本信明：首都圈における「持借混合」共同住宅の実態一住宅統計調査 の特別集計にもとづく「持借混合」問題の実証的研究（その 1$)-$ ，日本 建築学会計画系論文集，No.498，pp.169 176, 1997.8

21) 森田優三, 久次智雄 : 新統計概論改訂版, 日本評論社, p.271, 1993

22)Sylvie Dibos-Lacroux, Emmanuelle Vallas-Leners : La Copropriété de A à Z 2009, Editions Prat, 2009 